\title{
Becoming Workers of Greater France: Vocational Education in Colonial Morocco, 1912-1939
}

\author{
Michael A. Kozakowski
}

For two days in December of 1925, the teachers, school directors, and administrators of French Morocco gathered in Rabat to discuss the future of colonial education. Under the leadership of Georges Hardy, director-general of public education, fine arts, and antiquities in Morocco, they met in the Institut des Hautes études marocaines. The building's architecture reflected their ambition: to acknowledge Moroccan shapes and patterns, but to construct a modern and practical edifice. ${ }^{1}$ Hardy was emphatic: "agreement has been established around a catchphrase: 'The education of indigenes will be vocational or it will not be."'2

${ }^{1}$ Gwendolyn Wright, The Politics of Design in French Colonial Urbanism (Chicago: University of Chicago Press, 1991), 123.

${ }^{2}$ Georges Hardy, "Du souq à l'usine: Congrès de l'Enseignement Professionnel Indigène," Bulletin de l'enseignement public du Maroc, no. 72 (February 1926): 2.

M. A. Kozakowski $(\square)$

Keele University, Newcastle, UK

e-mail: m.a.kozakowski@keele.ac.uk

(C) The Author(s) 2020

D. Matasci et al. (eds.), Education and Development in Colonial and Postcolonial Africa, Global Histories of Education, https://doi.org/10.1007/978-3-030-27801-4_7 
Such a catchphrase summed up the theme of the appropriately entitled, Conference on Indigenous Vocational Education.

Yet there was more to such an agenda, Hardy noted, than a simple phrase, "because it is the fate of simple expressions to be incomplete." 3 In addition to the complexity of vocational reforms for the indigenous population, to whom Hardy referred in the conference, there was an equally complex and far-reaching series of reforms targeting the protectorate's French and foreign European populations. Indeed, vocational education was nothing less than a policy by which he and other French colonial administrators intended to build the educational, economic, social, and racial future of Morocco. A multifaceted, vocational emphasis, implemented through interlocking initiatives and across a variety of Moroccan school types (themselves differentiated by intersecting categories of class, gender, race, and urbanization), promoted a form of "adapted modernity" that aimed to promote modernization and incremental development without social disruption (see Chapter 1 by Damiano Matasci in this book).

For Hardy and other administrators, adopting a policy of vocational education in the interwar period meant implementing three interrelated reforms. First and most prominently, it meant establishing a system of vocational and technical schools [l'école professionnelle, or later, l'école d'apprentissage, as well as the école technique]. It also included efforts to make other schools more career-oriented, for example, by teaching drawing, agriculture, applied mathematics, and for girls, home economics. Finally, it meant creating institutions and methodologies to provide vocational guidance [orientation professionnelle, or as it is referred to in contemporary France, orientation scolaire et professionnelle]-a process to direct students to the right career and the appropriate training based on individual aptitude and social need.

Vocational education in all three of its forms represented a shift in thinking about the purpose of education, producing not just loyal subjects or intelligent humans, but workers of an industrializing "Greater France" [la plus grande France]. For interwar promoters like Albert Sarraut, "Greater France" evoked a vision of "100 million Frenchmen" between the metropole and colonies, not necessarily equal, but united in

${ }^{3}$ Ibid., 2. 
increasing the security and prosperity of France. ${ }^{4}$ In this context, vocational education promised to "rationally" and "efficiently" develop the human resources of Morocco so as to increase its economic productivity and ties to France in this strategy of mise en valeur (for other case studies, see Chapter 4 by Romain Tiquet and Chapter 6 by Caterina Scalvedi in this book). ${ }^{5}$ At the same time, a proper vocational education would allegedly mitigate the dangers of new social aspirations and resulting conflicts that both economic development and education could produce. ${ }^{6}$ As such, vocational education institutionalized and reinforced notions of class, race, religion, and gender through separate school systems and differentiated implementation of vocational reforms.

The increasingly broad literature on colonial education (often synonymous with the education of indigenous peoples) frequently points to vocational and "adapted" characteristics of education for indigenous peoples as a defining trait of "colonial" education. ${ }^{7}$ This chapter agrees that one of the defining traits of Moroccan education in the French protectorate during the interwar, colonial period was that it indeed had a strong vocational imprint and orientation. However, this vocational focus was characteristic of many types of schools and different

${ }^{4}$ Martin Thomas, "Albert Sarraut, French Colonial Development, and the Communist Threat, 1919-1930," Journal of Modern History 77, no. 343"(December 2005): 917; Josep M. Fradera, "La Plus Grande France: el ciudadano y su negación en la República imperial," in La nación imperial, vol. 2 (Barcelona: Edhasa, 2015), 973.

${ }^{5}$ Gilbert Rist, The History of Development: From Western Origins to Global Faith, trans. Patrick Camiller (London: Zed Books, 2010), 48-52; Frederick Cooper, Decolonization and African Society: The Labor Question in French and British Africa (Cambridge: Cambridge University Press, 2010), 32, 71; Alice Conklin, A Mission to Civilize: The Republican Idea of Empire in France and West Africa, 1895-1930 (Stanford: Stanford University Press, 1997), 212.

${ }^{6}$ Spencer D. Segalla, The Moroccan Soul: French Education, Colonial Ethnology, and Muslim Resistance, 1912-1956 (Lincoln: University of Nebraska, 2009), 151-152; Conklin, Mission to Civilize, 70-79.

${ }^{7}$ Segalla, Moroccan Soul, 155; Mohamed Benchekroun, L'éducation et l'enseignement au Maroc à travers les documents français et espagnols, 1912-1956: essai de bibliographie critique (Rabat: [s.n.], 1985); Elsie Rockwell, "Tracing Assimilation and Adaptation Through School Exercise Books from Afrique Occidentale Française in the Early Twentieth Century," in Empire and Education in Africa, ed. by Peter Kallaway and Rebecca Swartz (New York: Peter Lang, 2016), 235; Sybille Kuster, “'Book Learning' Versus 'Adapted Education': The Impact of Phelps-Stokesism on Colonial Education Systems in Central Africa in the Interwar Period," Paedagogica Historica 43, no. 1 (2007): 79. 
groups of students in interwar Morocco, including indigenous Muslims, indigenous Jews, who occupied a liminal position in French North Africa and were viewed as neither fully "native" nor fully "European," as well as European settlers.

This finding points to the inadequacies of viewing colonial education as exclusively - or even primarily - as indigenous education. For example in 1936, "Muslim" education received less than $22 \%$ of the educational budget. French and foreign students comprised half of the student population (in both vocational and non-vocational schools), and indigenous students with Muslim and Jewish juridical status split the remaining half. This was despite the fact that $94 \%$ of the total population was Muslim, 2.5\% were indigenous Jews, and the remaining 3\% were French and foreign. ${ }^{8}$ Just as education in the protectorate was often targeted at non-Muslim youth, this chapter finds that much of the vocational inflection of this school system was aimed at-and was more successful in attracting students from-European and indigenous Jewish communities. Across all communities, vocational reforms left a greater mark on the philosophy, rhetoric, and ambition of education than on student outcomes. However, insofar as students benefited from vocational education, they tended to be European and indigenous Jewish (on this issue, see Chapter 5 by Jakob Zollmann in this book).

Viewing vocational training as a project responding to European and governmental elites' ambitions and fears, and targeting just as much European and Jewish as Muslim students, helps make sense of two puzzles. The first is how vocational training could be imagined as promoting modernization-strongly associated with social disruption-while preserving social stability. It was not just that vocational training was imagined as a less disruptive path to modernity; it was also imagined that a modern workforce could be created for the protectorate while leaving much of the population in situ (and uneducated). Second, administrators acknowledged by the mid-1920s that they had failed to attract Muslim students to vocational training or provide a credible path to jobs after graduation. Nonetheless, vocational training continued to be a cornerstone of interwar education in French Morocco and an inspiration for both subsequent decades and parts of Morocco not directly controlled by the French. Simply put, vocational education could

\footnotetext{
${ }^{8}$ Yvette Katan, "L'école, instrument de la modernisation sous le protectorat français au Maroc?” Mediterrán tanulmányok 5 (1993): 110-112.
} 
continue, despite largely failing Muslim students, because it was not just designed with them in mind, and protectorate officials were unwilling to countenance or fund mass, general education until very late in the protectorate.

None of this is to minimize the fact that vocational training was highly racialized in its conceptions, reflected essentializing (and demeaning) assumptions about students' psychological and physical capabilities, and was highly unequal in both its quality and in the opportunities it provided. It was all of these things, as demonstrated in the first section, which focuses on protectorate politics, developmental ambitions, and their impact on Muslim schools in particular. Yet only through an examination of other communities, schools, and vocational programs outside of schools (in the second section), does one gain an appreciation for the broader ambitions of vocational reforms. In no small part because of this broader ambition and target audience, the very real and visible failures of vocational education, particularly in attracting Muslim students and securing them jobs (as shown in the third section), did not stop the continuation and even expansion of vocational education (as shown in the final section).

\section{The Politics of Muslim Vocational Education}

Vocational training was an integral part of the French educational system in Morocco from nearly the beginning of the protectorate in 1912. This marked a departure from earlier educational traditions, whereby indigenous Koranic schools had focused on teaching literacy and religion, with higher education positioning students for careers in government, law, and religion. In contrast, both manual trades and occupations like commerce were typically learned through apprenticeships and other direct training in the workplace, either after or instead of the years of Koranic education. World War I had delayed the implementation and expansion of French educational policies due to its disruptive effects on priorities, economic resources, students, and personnel. However, already in 1917, the Directorate of Education had converted a handful of urban schools for Muslims to vocational schools. That same year, the Industrial and Commercial School was opened in Casablanca. A private association, the Association of Commerce, Industry, and Agriculture (ACIA), which advocated for apprenticeships, also created night classes in trades and in French, open to members of all religions and backgrounds. When 
Resident General Marshall Lyautey invited Georges Hardy to become the second director-general of education in 1920, in the renamed Directorate of Public Education, Fine Arts, and Antiquities (DIP), a position he would retain until 1926, Hardy inherited a school system still in its formative years. With the support of Lyautey, he was to endow it with its vocational character and attention to ethnicity and class. These hallmarks were to be continued by his successors until World War II. ${ }^{9}$

While Hardy is infamous for his highly racialized views of indigenous students' psychology, which fit well with Lyautey's avowedly “associationalist" policies, ${ }^{10}$ one of Hardy's core objectives was to imbue this still nascent educational system with a strong vocational philosophy. Almost as soon as he took over the reins of the department of public education, the number of articles about vocational education appearing in the department's monthly bulletin, the Bulletin de l'enseignement public du Maroc, increased dramatically. Bringing together his experiences in French West Africa, the examples of education in Algeria and Tunisia, and trends in the metropole, Hardy viewed traditional French education as ill-suited to the needs of colonial students. Instead, he believed they required what is frequently termed an "adapted education," a philosophy that gained increasing prominence in Francophone and Anglophone African education in the 1920s, not least due to the work of the Phelps Stokes commission. ${ }^{11}$ Largely speaking, his vision was compatible with that of Lyautey. While Lyautey was particularly interested in forging close bonds with the Moroccan elite, resulting in specially designated

\footnotetext{
${ }^{9}$ Lucien Paye, Introduction et évolution de l'enseignement moderne au Maroc (Paris: [s.n.], 1957); Segalla, Moroccan Soul, 35; Louis Brunot, "Histoire de l'enseignement des indigènes musulmans," in Premiers Conseils (Rabat: Ecole du Livre, 1934), 137, 138, 151; Georges Hardy, L'âme marocaine d'après la littérature française (Paris: É. Larose, 1926); Georges Hardy and Louis Brunot, L'enfant marocain: Essai d'ethnographie scolaire (Paris: E. Larose, $1925)$.

${ }^{10}$ Segalla, Moroccan Soul; Mohammed Rachid Belhaj Saif, "La politique scolaire du protectorat français au Maroc, 1912-1940," Thèse État, Université René Descartes Paris V, 1994.

${ }^{11}$ Kuster, “'Book Learning' Versus 'Adapted Education'," 83; Udo Bude, "The Adaptation Concept in British Colonial Education," Comparative Education 19, no. 3 (1983): 341-355; Pascale Barthélémy, Emmanuelle Picard, and Rebecca Rogers (eds.), "L'enseignement dans l'empire colonial français (XIXe-XXe siècles)," Histoire de l'éducation 128 (2010); Laurent Manière, "La politique française pour l'adaptation de l'enseignement en Afrique après les indépendances (1958-1964)," Histoire de l'éducation, no. 128 (2010): 163-190.
} 
schools for sons of Moroccan elites, he also placed a high emphasis on basic, general education and the French language for indigenous students of humbler backgrounds. ${ }^{12}$ European economic elites, however, tended to distrust education for Muslim students (and the aspirations they feared would accompany such an education), preferring to train any workers they needed through on-site apprenticeships. Beyond arguments about economic productivity, critics of "general education" feared that it would give students "useless knowledge" and more worryingly, "overly excite them," to use contemporary euphemisms, to protest, to rebel (as in the Spanish protectorate during the Rif War), or to strike (as in 1918 and 1919).

These differing objectives by different stakeholders resulted in a highly fragmented school system. In theory, education was "open to children of all nationalities and to all religions." 13 In practice, it had limited resources, limited appeal, and uneven enrollment. Lyautey adopted an explicitly "associationalist," rather than "assimilationist" educational policy, in which Moroccan subjects' local identities were reinforced, even as they were taught to participate in the French-dominated life of the protectorate. ${ }^{14}$ Thus, there were separate school systems for "Europeans," "Muslims," and "Jews," as administrators most commonly divided the population. Schools were further segregated according to gender, and in practice, on the basis of class. While there were designated "Berber" schools in several rural areas, the construct of an Arab/Berber divide played a relatively minimal role in educational policy, in contrast, for example, to the poorly received "Berber Dahir" of 1930, assigning Berbers a distinct juridical status. ${ }^{15}$ Nonetheless, the result of all these

${ }^{12}$ Segalla, Moroccan Soul, 154-155.

${ }^{13}$ Gaston Loth, "Règlement scolaire," Bulletin de l'enseignement public du Maroc, no. 1 (June 1914): 1.

${ }^{14}$ Louis Brunot, "L'action colonial et les mentalités indigènes," in Premiers conseils (Rabat: Ecole du Livre, 1934), 154; Raymond F. Betts, Assimilation and Association in French Colonial Theory, 1890-1914 (New York: Columbia University Press, 1961); Belhaj Saif, La politique scolaire; Yvonne Knibiehler, "L'enseignement au Maroc pendant le protectorat (1912-1956): Les 'fils de notables'," Revue d'bistoire moderne et contemporaine 41, no. 3 (July-September 1994): 489.

${ }^{15}$ Patricia Lorcin, Imperial Identities: Stereotyping, Prejudice, and Race in Colonial Algeria (London: I.B. Tauris, 1995); Fanny Colonna, Instituteurs algériens, 1883-1939, Travaux et recherches de science politique, no. 36 (Paris: Presses de la Fondation nationale des sciences politiques, 1975). 
perceived differences was a variety of school types. For example in 1930, the Muslim population of Morocco was served by 15 schools for girls, 36 rural primary schools (of which 18 were designated as serving the Berber population), 25 urban primary schools, 14 schools of apprenticeship, six schools for the sons of notables, one regional Berber secondary school, and two Muslim secondary schools. All secondary schools, notably, were designated as a collège, and not the more advanced lycée, which would prepare students for the baccalauréat and entrance to universities. ${ }^{16}$

In theory, the Muslim vocational schools were designed to be secondary schools. In practice, in the early 1920s, the primary and vocational schools operated on parallel tracks for similarly aged pupils, rather than in subsequent order. Another compromise was that both primary and vocational schools tended to incorporate elements of both general and vocational education. Particularly in the latter half of the 1920s, the urban primary schools and rural schools cultivated those subjects, skills, and mindsets administrators imagined would increase economic productivity and a vocational orientation. Thus, primary school students received an hour and a half of daily "pre-apprenticeship" training to practice their manual dexterity, to familiarize them with basic tools, and to pique their interest in manual trades. In rural schools, as well as in many urban schools, the curriculum reflected the central role of agriculture in the Moroccan economy. For example, students were taught the vocabulary and basic principles of agriculture in leçons de langage and leçons de choses. These schools were also equipped with school gardens in which students worked, and often a school cooperative [mutuelle] in which products were sold. In these efforts, administrators sought a balance between the agricultural practices used by students' families and the practices used by the European settlers, who often had larger plots, grew different crops, or used more capital-intensive techniques. Rather than reinforcing old practices or potentially "disorienting" students, administrators sought to instruct students about "improved agriculture" that avoided both extremes. ${ }^{17}$ Yet these compromises pleased few. For example, pupils

\footnotetext{
${ }^{16}$ Brunot, "Histoire," 145, 151.

${ }^{17}$ Louis Brunot, "Circulaire aux directeurs des écoles rurales et des écoles urbaines donnant un enseignement agricole," in Premiers conseils (Rabat: Ecole du Livre, 1934), 188 .
} 
often complained about the gardens, seeing them as demeaning and an excuse to extract cheap labor. ${ }^{18}$

The explicitly designated Muslim vocational schools-and the compromises on which they were founded-also struggled to gain support from pupils, their families, and the business community. These dedicated vocational schools [l'école professionnelle], or later, "schools of apprenticeship" [écoles d'apprentissage], provided more specialized training in the manual trades. Both the physical plant of the vocational school and its curriculum reflected its dual mandate (another compromise) to provide an education in both "general culture" [culture générale] and in a trade [métier]. General culture was taught in the classroom, whereas the trades were learned in school workshops, where students served apprenticeships. As a further compromise between partisans of these two different types of education, the lessons in the classroom were tailored to their potential application in the workshop, for example, by emphasizing the relevant technical vocabulary. ${ }^{19}$ Directors of vocational schools saw their mission as creating the workers necessary for a modern economy, for "today's jobs demand, in effect, specialist workers," as one director wrote. ${ }^{20}$ However, they generally realized that traditional (nonschool) apprenticeships more than adequately taught manual skills. What Moroccan (and European) apprentices needed to be competitive in a European-dominated workplace, they argued, were the basics of French, math, drawing, and introductions to the organization and method of European work. Through specialization, vocational schools promised to transform the masses of laborers [main-d'ouevre] into skilled or semiskilled workers [ouvriers]. There was, admittedly, some disagreement about the degree of this specialization to be taught in school. For example, the director of Muslim education, Louis Brunot, felt that it was the role of vocational education to create semi-skilled workers, who would acquire the rest of their skills in their place of employment. In contrast, a Casablanca educator, Martial Lisard, felt that a worker who did not learn a trade remained only a "half-worker" [demi-ouvrier], in a derogatory

\footnotetext{
${ }^{18}$ Segalla, Moroccan Soul, 166.
}

${ }^{19}$ Mauguière et Achille, "Le problème de la culture générale," Bulletin de l'enseignement public du Maroc, no. 72 (February 1926): 31-34.

${ }^{20} \mathrm{M}$. Lisard, "L'orientation professionnelle au Maroc: Organisation et fonctionnement du Bureau d'Orientation professionnelle de Casablanca (Année 1927-1928)," Bulletin de l'enseignement public du Maroc, no. 93 (January 1929): 18. 
sense. Yet most educators agreed that some degree of labor specialization was necessary, and that it required external coordination for this specialization, perhaps by the state. ${ }^{21}$

The types of trades that students learned in vocational schools varied by institution. Most of the approximately fifteen Muslim vocational schools for boys in operation at the end of 1925 prepared students for "trades such as are practiced in Europe with modern tools and processes," mostly involving wood and iron. ${ }^{22}$ Many of these students learned relatively common jobs like carpentry or mechanics, but with specialized training and exposure to the latest techniques if facilities and trained overseers allowed (and neither was to be taken for granted). In a few schools, there were also electrified workshops. A minority of vocational schools were oriented toward Moroccan arts: as of the mid-1920s, two schools for boys taught cabinet-making, an additional two taught leatherwork and bookbinding, and one taught leather embroidery and woodworking. Furthermore, the five vocational schools for Muslim girls taught pupils to weave carpets and mats. ${ }^{23}$

These vocational schools for girls served the dual function of creating "traditional" art and providing women with a basic education that could overcome the objections of some religious conservatives. For Hardy, instruction in indigenous art served also as a means of preserving and restoring the originality of Moroccan art. These efforts meant producing luxurious, "authentic" Moroccan art to rescue it from its supposed corruptions by European techniques, motifs, and cost-cutting, even if tourists might not be able to appreciate or afford it. ${ }^{24}$ More broadly, his and Lyautey's "preservation" policies positioned the French as defenders of Islam, of Moroccan culture, and of social stability. This was a calculated move to win the support of local elites and to minimize the likelihood of revolt, while simultaneously stimulating the economy through tourism. ${ }^{25}$ Hardy's department, which oversaw public education, fine arts, and antiquities, assisted with all these requirements. In 1920, the

${ }^{21}$ Lisard, "L'orientation professionnelle," 18; Brunot, "Histoire," 143.

${ }^{22}$ Roger Gaudefroy-Demombynes, L'æuvre française en matière d'enseignement au Maroc (Paris: P. Geuthner, 1928), 89.

${ }^{23}$ Ibid., 89, n. 2.

${ }^{24}$ Baldoui, Hainaut, and Le Gozler, "Les écoles professionnelles et l'art indigène," Bulletin de l'enseignement public du Maroc, no. 72 (February 1926): 60, 62.

${ }^{25}$ Wright, Politics of Design, 89-90. 
DIP's Service des arts had assumed control of training in handicrafts before integrating this training into vocational and urban schools two years later. ${ }^{26}$ Thus, while part of Hardy's directorate preserved historic sites, its vocational schools trained workers to produce carpets, leather goods, embroideries, and small wooden objects with inlay for purchase. It was but one of several examples where Lyautey and Hardy mobilized their conceptions about ethnographic difference and the "authentically Moroccan"-whether expressed in art, architecture, or personhood-to promote economic development.

State-run schools so explicitly oriented to the needs of the economy represented a shift in how French colonial and metropolitan administrators thought about education. While elite technical schools had existed in France for some decades, vocational schools and the regulation and "scholarization" of apprenticeships were expanded during the first half of the twentieth century. In addition to an increased average time children spent in state schools, raising the question of what to with them in school, there was an increasing sense among French policymakers before and immediately after World War I that the country needed to increase its economic output to counter the threat of Germany to national security. This insecurity was coupled with a recognition that modern industries like metallurgy required skilled workers in narrow, specialized jobs. These were jobs for which traditional apprenticeships, general schools, or even on-the-job training appeared inadequate. Consequently, early twentieth-century French governments looked to increase collaboration with industry, standardize technical training, expand access to vocational schools, and even in non-vocational schools, make a clearer connection between pupils' education and their future jobs as workers. The new role of public education, as one teacher at the School for Industry and Commerce in Casablanca envisioned, would be "to prepare the citizen and the producer." 27

In this particular form of linking the development of individual productivity to the productivity of the country, vocational education fit within a new, if still embryonic, vision of economic development. The French phrase increasingly heard during the period of roughly 1890 to 1950 , particularly in the colonies, was "mise en valeur," which

\footnotetext{
${ }^{26}$ Segalla, Moroccan Soul, 160.

${ }^{27}$ Jacquemet, "L'école primaire et l'orientation professionnelle," Bulletin de l'enseignement public du Maroc, no. 58 (April 1924): 267.
} 
has a sense of "putting to productive use," "increasing the value," or "developing." 28 More than just ensuring that schools were producing physically fit and specialized workers, vocational education was also intended to create specific types of modern, manual workers with a scientific outlook corresponding to the needs of the evolving colonial economy. Whereas French public education had always been designed to transmit the moral values of hard and honest work, the reformed school would also teach the skills of industry and develop the productive capacity of its pupils. As one pair of presenters reported to the Conference on Indigenous Vocational Education, Morocco was undergoing drastic economic and social change, and vocational education was designed to facilitate a skilled workforce for this modern, "European" economy. ${ }^{29}$ In this new economy, these educators specifically promoted industry and manual trades, rather than purely intellectual professions. ${ }^{30}$ It was not that administrators did not want skilled bureaucrats or white-collar workers. Rather, they realized that the supply of such jobs was limited, that they could attract applicants without government support on account of their pay and easy working conditions, and believed that they did not directly boost production.

In this context, a vocational education with sensitivity to ethnicity and class and producing more industrious and specialized labor combined the promise of increased productivity and economic development while minimizing challenges to French authority. One perceived risk that contemporary commentators on education feared was the threat that a Moroccan "proletariat" might emerge, in the words of Gaudefroy-Demombynes. ${ }^{31}$ To navigate the perilous "passage from "the souk to the factory," "as he and Hardy referred to it, a rigorous policy response was needed. Like his contemporaries, Hardy emphasized the need for specialization, regulation, and productivity at the

${ }^{28}$ Belhaj Saif, La politique scolaire, 53-74; Rist, History of Development; Corinna Unger, International Development: A Postwar History (London: Bloomsbury, 2018).

${ }^{29}$ Morisson and Montel, "Le recrutement des élèves et la fréquentation," Bulletin de l'enseignement public du Maroc, no. 72 (February 1926): 20-21.

${ }^{30}$ Louis Brunot, "Certificat d'études primaires et apprentissage," in Premiers conseils (Rabat: Ecole du Livre, 1934), 203.

${ }^{31}$ Gaudefroy-Demombynes, L'auvre française, 102-103. 
same time as the need to keep students rooted in social structures, lest they become declassed or uprooted. ${ }^{32}$

The social stability that vocational education promised both increased productivity and maintained students "where they belonged," that is, in their appropriate family, occupational, class, and ethnographic settings. Hardy and other educators were well aware-and to an extent regretted-that vocational education reinforced class divisions. They lamented, for example, that poor European families often had to send their children into the workforce as soon as possible, rather than pursue further education, and that the indigenous Moroccan elite families embraced a system that sent poor children to manual trades while preparing their own for administrative careers. Acceptance of class division was the norm in educational policy, not least because education officials were skeptical of the ability of education to change class structures. They were also more afraid of social instability than desirous of social mobility. ${ }^{33}$ Thus, rather than making an effort to counteract class division to "democratize a society," administrators, as Inspector Paul Marty bluntly put it, "consider men and things such as they are...The child of a given social milieu should receive an education that is adapted to that milieu, that will maintain him there, and will render him more able to fulfill his social role, however humble it may be." 34 In accepting that class was going to be reproduced in the school system, administrators instead focused on ensuring that sufficient numbers entered the manual or "productive" trades, and that those who did would receive rigorous and specialized training. ${ }^{35}$

\section{Vocational Education Beyond the Indigenous Classroom}

Specialization and economic development were likewise the objectives of vocational schools and programs designed for non-Muslim students. The DIP, Alliance israélite universelle, and Comité israélite pour l'orientation professionnelle worked together to create a Jewish school of apprenticeship in Casablanca, whose curriculum emphasized wood and iron work,

\footnotetext{
${ }^{32}$ Hardy, "Du Souq," 3.

${ }^{33}$ Lisard, "L'orientation professionnelle," 19; Hardy, "Du Souq," 3.

${ }^{34}$ Paul Marty, Le Maroc de demain (Paris: Comité de l'Afrique française, 1925), 142.

${ }^{35}$ Lisard, "L'orientation professionnelle," 16-18.
} 
design, technology, French, and math. These associations also strove to encourage vocations in industry and agriculture. The "European" school of apprenticeship in Rabat had 24 Muslim and 63 non-Muslim students in 1930. Both Rabat and Casablanca hosted schools where European girls aged 12-16 learned home economics (école ménagère). Yet much of the vocational orientation for European and Jewish students was for boys and took place either at the level of the curriculum, for example, in so-called complementary courses (cours complémentaires), or through specialized, technical schools. ${ }^{36}$

The specialized technical schools-rather than vocational and apprenticeship schools (l'école professionnelle or l'école d'apprentissage)—taught more technologically advanced jobs and tended to cater to European students, though they were open to indigenous Jews and Muslims, as well. The most famous institution was the Industrial and Commercial School in Casablanca [l'Ecole industrielle et commerciale], which opened in 1917 to all religions and nationalities. It trained technicians and managers in electricity, public works, agriculture, and administration. By 1928, it trained approximately 400 students, including those completing apprenticeships, further education, preparatory classes, preparation for university, and professional certificates. ${ }^{37}$ An elementary school dedicated to maritime industries opened in 1931 in Casablanca. There was also a specialized school for agriculture in Fez. By 1934, vocational and technical schools offered training in electricity, zinc-plumbing, locksmithing, and car repairs, while agricultural mechanics and automobile bodywork were under consideration. ${ }^{38}$

In addition to promoting modern industries and techniques in general, vocational education also targeted export industries. A school was established at Kourigha in 1924 under the patronage of the Office des Phosphates. Phosphates were and remain to this day a principal export from Morocco. In Kourigha, students learned wood and iron work, and plans were afoot in 1925 to expand teaching to include mining and electricity, all with the aim of creating skilled workers for the phosphate

\footnotetext{
${ }^{36}$ Morocco, Direction Générale de l'instruction publique, des beaux-arts et des antiquités (DIP), Historique, 1912-1930 (Rabat: Imprimerie de l'École du livre, 1930), 41, 46.

${ }^{37}$ Morocco, DIP, Historique, 31-33.

${ }^{38}$ Brunot, "Histoire," 143.
} 
industry. ${ }^{39}$ While the school might have represented an extreme example, the linkages between trade and education were clearly on the mind of Henri Velu, who justified the teaching of agricultural science in the elementary school due to the fact that, apart from phosphates, most export earnings from Morocco were agricultural. ${ }^{40}$

Yet a vocational emphasis to education was not simply a matter of creating dedicated schools, nor simply a preoccupation toward one group of students. In order for the nation's members to put their state-provided education to productive use, all students had to be made aware of the path between school and career. When Hardy's successor, Jean Gotteland, lamented in 1932 of the "disquieting" "number of young boys and young girls who pursue here their [secondary] studies... without having any idea of the use that they will be able to make of their knowledge...," the students he had in mind were Europeans, although he feared that in time Moroccan Muslims and Jews would follow their example. ${ }^{41}$ The solution, pursued in most major Moroccan cities since the mid-1920s, was to create a system for students to learn about which profession they would be suited for, the potentials and limitations of such a profession, and how to best prepare for such a career, including what type of further education (if any) was most appropriate. ${ }^{42}$

When established in places like Casablanca, the offices for vocational guidance [Bureaux d'orientation professionnelle] pursued activities that were typical for such offices in Europe. For example, they interviewed local leaders of industry to create brochures that they would distribute to students about the working conditions and prospects for common jobs. They charged teachers and school physicians with creating card files [fiches] for every student with information about the student's scholastic, moral, physical, and psychological aptitudes. Finally, they counseled students based on their aptitudes and interests, and when possible placed

\footnotetext{
${ }^{39}$ Gaudefroy-Demombynes, L'auvre française, 91; Congrès de l'Enseignement Professionnel Indigène [Rabat 1925], "Situation des écoles d'apprentissage d'indigènes actuellement existantes," Bulletin de l'enseignement public du Maroc, no. 72 (February 1926): 86-88.

${ }^{40} \mathrm{H}$. Velu, "L'enseignement agricole élémentaire," Bulletin de l'enseignement public du Maroc, no. 89 (May 1928): 156-161.

${ }^{41}$ Jean Gotteland and Mlle Alphandery, "A propos d'Orientation professionnelle," Bulletin de l'enseignement public du Maroc (November-December 1932): 449.

${ }^{42}$ Morisson and Montel, "Le recrutement," 23.
} 
them directly in apprenticeships. For example, during the 1927-1928 academic year, fifty-nine European students and families sought counseling in the Casablanca office. Of these, seven students were reportedly dissuaded from their choice of profession due to adverse economic conditions. Another seven with medical counterindications were directed to corrective medical care and to more appropriate trades. Five students were redirected because of their academic deficiencies, three were helped to make a decision, and thirty-seven were "permitted" by the office to exercise their choice of job. In fact, the vocational guidance office had no legal authority, so whether any of the students actually complied with the recommendations is unclear. ${ }^{43}$

Vocational guidance aimed to "scientifically" track students to the most appropriate and specialized careers, ensuring maximum efficient use of every laborer. Specialization was a hallmark of industrializing society and, as such, had been a secular trend for many decades. However during World War I and through the 1920s, French businessmen and policymakers looked to deliberately promote specialization by adopting "American" techniques, often associated with "Taylorism," such as time-motion studies, specialization of tasks, the determination of the optimal way to perform every step of a task, the recruitment of the right worker for a very specific job, and the restructuring of wages to reward increased output. ${ }^{44}$ A key educator involved in the vocational guidance movement in Casablanca, Martial Lisard, expressed this ambition in his claim that, "social life rests on a just equilibrium of diverse activities, rationally coordinated in view of the common good," 45 while others lauded vocational orientation as a "powerful factor of social peace." 46 While vocational guidance did not derive strictly from Taylorism, the two movements were mutually supportive. Both movements sought to recruit the "right man for the right job," to increase specialization and mastery of tasks (for vocational guidance, through apprenticeships), and to "rationalize"

${ }^{43}$ Lisard, "L'orientation professionnelle," 22-23; Edouard Gauthier, "L'orientation professionnelle," Revue Internationale du Travail 5, no. 5 (May 1922): 759-773.

${ }^{44}$ Elisa Camiscioli, Reproducing the French Race (Durham, NC: Duke, 2009), 51-74; Charles S. Maier, In Search of Stability: Explorations in Historical Political Economy (Cambridge: Cambridge University Press, 1987), 19-69.

${ }^{45}$ Lisard, "L'orientation professionnelle," 13.

${ }^{46}$ Gauthier, "L'orientation professionnelle," 761. 
the workforce, for example, by directing students away from trades with a surplus of labor and toward other careers.

Ideally, individuals would benefit by pursuing a career that was interesting, practical, and financially rewarding. At the same time, society would benefit through increased specialization, the elimination of "waste," improved health, and the encouragement of students to pursue the most productive jobs. For example, the "scientific tracking" of students to the jobs they were physically suited for-facilitated by medical record cards completed by school physicians-promised to protect the individual and corporate health of the workforce. ${ }^{47}$ Vocational counselors routinely directed students away from careers that they were not fit for, fearing that inappropriate placement would result in "bodily fatigue, as much as that of intellectual tension." 48 Some of this focus on medicine was clearly designed to give the vocational guidance movement the respectability of "science" as it directed individuals to particular jobs. ${ }^{49}$ However, it was also part of a broader movement that thought about bodily health as a link between individual and collective health, the availability of future soldiers, and the productivity of future workers.

\section{The Limits of Vocational Training}

Although vocational thinking had a deep imprint on educational philosophy and curriculum, both within and beyond schools, themselves, several factors limited its impact on students, and particularly on Muslim students. In part, vocational training in interwar French Morocco was limited by the scope of public education, more generally. The number of students enrolled in Moroccan schools increased steadily from year to year, but from a low base. Enrollment was proportionally higher among the European population, while the total number of indigenous students enrolled in school was extremely modest-less than 10,000 in 1929 and less than 16,000 in 1933 . Out of this population, the number of

\footnotetext{
${ }^{47}$ Gotteland and Alphandery, "A propos," 449; Montel and Morrison, "Le recrutement," 24; Lisard, "L'orientation professionnelle," 15; Gauthier, "L'orientation professionnelle," 759-773.

${ }^{48}$ Gauthier, "L'orientation professionnelle," 761-762.

${ }^{49}$ Mary Louise Roberts, Civilization Without Sexes: Reconstructing Gender in Postwar France, 1917-1927. Women in Culture and Society (Chicago: University of Chicago Press, 1994), 190-191.
} 
apprentices in the French-controlled system varied greatly from year to year: down to 500 apprentices in 1930 from highs in the mid-1920s, then returning to 1155 apprentices in $1933 .{ }^{50}$ Other programs like vocational guidance efforts, pre-apprenticeship classes, and school gardens increased the impact of vocational orientation outside the formal vocational schools, but it was still a minority of school-age children who attended school in interwar Morocco and a minority of those who attended explicitly vocational programs.

Part of the dynamic was that families shied away from vocational schools and programs. Muslim parents, it was lamented, "cannot conceive that a trade is taught in a school... One puts a child in school so that he is not a worker like his father. If, on the contrary, the parents really want to teach their son a trade, they prefer to entrust him to an artisan of the souk." ${ }^{51}$ Preference for an "intellectual" education was also prevalent, if less commented upon, among other ethnic groups. Even if parents wanted to send their students to vocational school, the high cost of living and the availability of jobs that did not require prior training drove youth and their families toward immediate employment, rather than the possibility of higher earnings in a more distant future. ${ }^{52}$

When students did enroll in vocational schools, they did not always stay for long or have better career opportunities. The average student during the mid-1920s spent a few weeks or months at a vocational school, rather than the minimum of three years that one was said to need to learn a profession. ${ }^{53}$ Instead, students often left as soon as they could find a job, even though this generally meant lower, if more immediate, salaries. Moreover, the training provided in vocational school did not provide a guaranteed return on investment. A lively debate at the time considered whether specialized schools actually depressed wages in the professions they taught by producing a surfeit of workers. While statistics are imprecise, the evidence suggests that graduates were most likely to find jobs in coastal cities with a strong European commercial presence, such as Rabat-Salé, Tangier, Casablanca, and Mazagan (El-Jadida), whereas students in inland cities most associated with

\footnotetext{
${ }^{50}$ Brunot, "Histoire de l'enseignement," 142.

${ }^{51}$ Morisson and Montel, "Le recrutement," 19.

${ }^{52}$ Lisard, "L'orientation professionnelle," 17-18.

${ }^{53}$ Gaudefroy-Demombynes, L'auvre française, 94.
} 
traditional Moroccan society, such as Fez or Marrakech, or who studied indigenous art in places like Oujda or Mogador, had difficulty finding jobs. ${ }^{54}$ Moreover, many employers refused to take apprentices, preferring to teach most workers on the job and to bring a handful of skilled workers from France if their needs were not met locally. ${ }^{55}$ The effect on students in Muslim vocational schools was pronounced. According to the (admittedly imprecise) statistics reported in the 1925 Conference on Indigenous Vocational Education, only half of students leaving such schools found or chose work in the trade that they had learned. ${ }^{56}$

Surveys of students' career choices demonstrate that these failures of vocational education for Muslim students, coupled with greater access for indigenous Jewish and European students, led to very different expectations about careers when students left school. For three years between 1924 and 1926, the Bulletin de l'enseignement public published the results of surveys about students' vocational choices. At the request of Hardy, the oldest students in every school-i.e., those who were old enough to enter the workforce, rather than those who had obtained a certain level of schooling-were asked to respond to two questions: what profession they intended to practice upon leaving school, and the reasons for that choice. The survey had multiple limitations, as Hardy himself freely admitted, including the impossibility of knowing whether the responses reflect students' dreams, intentions, or even attempts to give the "right" or "wrong" response. ${ }^{57}$

Nonetheless, an analysis of the 1926 survey reveals that European primary school students were approximately twice as willing as their counterparts in Muslim schools to embrace manual jobs. It is possible that this result reflected less the impact of education than the fact that enrollment in European schools reflected a broader and more representative spectrum of society than Muslim schools. However, in both communities, there were pronounced class differences. For example, Muslim students in primary schools were approximately six times more likely to declare an intention for manual, non-agricultural jobs than those students attending the elite écoles des fils de notables. A similar, if less

\footnotetext{
${ }^{54}$ Congrès de l'Enseignement, "Situation des écoles," 76-93.

${ }^{55}$ Segalla, Moroccan Soul, 157.

${ }^{56}$ Lisard, "L'orientation professionnelle," 17.

${ }^{57}$ Georges Hardy, "Les vocations de nos élèves," Bulletin de l'enseignement public du Maroc (April 1924): 211.
} 
pronounced trend, is clear among the European community, where lycée students also eschewed manual professions. ${ }^{58}$

While many students wished to assume white-collar jobs, there were distinct differences in preference, based on background. No less than $44 \%$ of Jewish primary school students wished to assume jobs in commerce in 1926, mostly as shopkeepers but also as bookkeepers and bankers. Only a handful of Jewish students planned to enter public administration, which reflected both their political disadvantage and their limited opportunities for secondary education. In contrast, Muslim students preferred administration over commerce, and both over manual trades. ${ }^{59}$ This preference was troubling for Hardy. Left to their own devices, he complained, the young Muslim bourgeoisie would all become petty bureaucrats. Although some indigenous administrators were necessary, the educational system should ensure that there were not too many aspiring bureaucrats and that only well-formed and well-chosen bureaucrats were hired. Finally, although European students also found public employment attractive, students in the prestigious lycées aspired to exercise more specialized and potentially more lucrative roles in an increasingly sophisticated economy as officers, civil engineers, teachers [professeurs, rather than instituteurs], doctors (of various specialties), and lawyers, rather than as junior civil servants. ${ }^{60}$

Among manual jobs, European students also best seemed positioned to take advantage of Morocco's economic growth. European students showed an appreciable interest in construction, which was something of a growth industry due to the influx of European immigrants who were housed in newly built sections of cities and due to public infrastructure projects. They expressed even more interest in mechanics, electricity, and engineering. In total, some $43 \%$ of European primary school students wished to work with metals, electricity, construction, or engineering. In contrast, virtually no Muslim students in the elite primary or secondary school systems were interested in such trades. The only Muslim school population to express interest in manual jobs, those attending primary

${ }^{58}$ Georges Hardy, "Les vocations de nos élèves," Bulletin de l'enseignement public du Maroc (May-June-July 1926): 82-144.

${ }^{59}$ Ibid.

${ }^{60}$ Hardy, "Du Souq," 14-16. 
schools, wished to work almost exclusively with wood as carpenters, joiners, or cabinetmakers (and again, at a lower rate than their European peers). Although vocational educators insisted on high-quality work and introduced more mechanized and electrified techniques into these trades, woodworking was considered less industrialized or "modern" than the metalworking, mechanics, and electricity that attracted European students. In short, students' job preferences closely reflected conceptions of modernity and the racialized hierarchies of the protectorate, more broadly, with the most industrial, technical, and "modern" trades attracting primarily European students, followed by indigenous Jews.

For all the shortcomings of vocational education program as implemented in Morocco, and despite its mission to preserve class and racial hierarchies, it did offer a modicum of social mobility. For example, within the European community, there was evidence that vocational education-and education more generally-fulfilled the aspirations of upward social mobility of Spaniards in French Morocco, who often hailed from the least economically and educationally regions of Spain. ${ }^{61}$ Among the indigenous Moroccan population, as was the case in France, pupils in vocational schools were often orphans, the sons of artisans whose trades faced an uncertain or declining future, or the sons of the petite bourgeoisie (who themselves often faced acute economic uncertainty). ${ }^{62}$ While these social origins may not have impressed contemporaries, it suggests that the students from all religions and backgrounds who accepted vocational education nonetheless saw it as a chance, however uncertain, of acquiring skills and providing either an improvement over their current socioeconomic situation or a hedge to preserve that status.

\section{INEFFECTIVE REFORMS AND EXPANSION}

The very real challenges of vocational education, particularly for indigenous Muslim students, inspired heated discussion in the 1925 Conference on Indigenous Vocational Education and led to change. As a result of the 1925 conference, a series of reforms doubled stipends for students in vocational schools, and administrators strove to

${ }^{61} \mathrm{~J}$. Vedel, "Les élèves espagnols des écoles du Maroc," Bulletin de l'enseignement public du Maroc, no. 56 (February 1924): 141-147.

${ }^{62}$ Morisson and Montel, "Le recrutement," 20. 
provide better connections between schooling and jobs. Given the lack of employer interest, however, these efforts came to little fruition. In practice, after 1926, there was a greater convergence between vocational and non-vocational schools for Muslims. Vocational schools placed an increased emphasis on general education, especially French and math. Meanwhile, five out of sixteen vocational schools were officially converted to primary schools. ${ }^{63}$

Nonetheless, vocational training continued to leave its mark on education in Morocco. While some scholars have seen a decreased focus on vocational training after 1926, particularly under Hardy's successor, Gotteland, who took his post that year, ${ }^{64}$ vocational education neither disappeared nor lost its importance (or resolved its challenges, for that matter). Gotteland was skeptical of vocational training's potential (and desirability) to modernize the country. However, there is little evidence that teachers, pupils, and their families-many of whom had long been aware of the system's shortcoming, substantially altered their perceptions. Rather, demand continued to increase for vocational training. Despite the conversion of five vocational schools to urban schools in 1926, the rebranding of vocational schools and opening of new locations meant that by 1930, there were 14 so-called schools of apprenticeship, nearly the same as before. ${ }^{65}$ Furthermore, from hardly 500 students enrolled in Muslim vocational schools around 1930, the total increased to about 1200 Muslim students in $1935 .^{66}$

Part of this countervailing dynamic was that demand for vocational schools increased, even as administrators began to acknowledge the challenges. Starting around 1926, the cumulative effect of a decade of economic changes brought about by the establishment of the protectorate and increased global trade, disrupting traditional handicrafts and leading to the loss of land, began to boost enrollment in Muslim schools. A majority of the pupils were the sons of the unskilled and landless. Families in traditional handicrafts and light industries often saw little benefit to the French-run schools, while elite families benefited from a separate school system. Many Moroccan families remained skeptical of the vocational

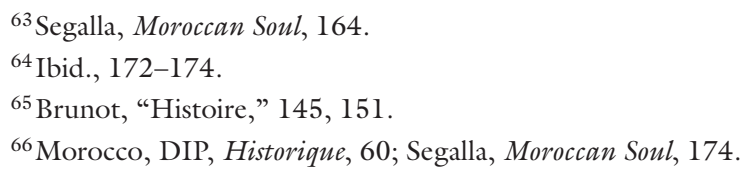


schools. However, limited budgets, and limited places for Muslim students in the state school system - far short of anything approaching universal, or even widespread, education-meant that vocational schools were one of the few opportunities to receive a formal education. By way of example, when France was invaded in 1940, less than $3 \%$ of Moroccan children had spots in French-run schools, and demand for education exceeded supply. ${ }^{67}$

Moreover, despite its numerous shortcomings-well acknowledged at the time-vocational education had an impact beyond the boundaries of the interwar French protectorate. For example, the "indigenous" vocational school in the international city of Tangier, whose students in 1925 included 22 Muslims, 30 Jews, and 10 Spaniards [sic], had a strong French influence. ${ }^{68}$ In the 1920s, the Alliance israélite universelle and Comité israélite pour l'orientation professionnelle, with the assistance of the DIP in the French sector, created workshops for sewing and embroidery in poor Jewish neighborhoods across Morocco, including Casablanca and Mogador (Essaouira) in the French protectorate, the international city of Tangier, and the capital of the Spanish protectorate, Tétouan. ${ }^{69}$

In the Spanish sector, authorities had long looked to French vocational reforms to inform their even more modest public education system. Spanish vocational education was by no means a slavish copy of a French model, having its own, local history and own tradition of participation in a broader international movement. Nonetheless, French efforts in Morocco were well known to Spanish school inspectors and other authorities, who approvingly quoted, for example, Paul Marty's claim that colonial education should not attempt to increase social mobility but train students for the position they were born into. ${ }^{70}$ The roots of vocational education in the Spanish zone date to 1923 , but it was not until the last years that the Second Republic exercised control over Morocco (1931-1936) that authorities slowly began to add workshops to primary schools. ${ }^{71}$

\footnotetext{
${ }^{67}$ Robin Bidwell, Morocco Under Colonial Rule (New York: Routledge, 1973), 253.

${ }^{68}$ Congrès de l'Enseignement, "Situation des écoles," 77.

${ }^{69}$ Morocco, DIP, Historique, 46.

${ }^{70}$ Luis Bello, Viaje por las escuelas de España, vol. 4 (Madrid: Magisterio español, 1926), 183-184.

${ }^{71}$ Federico Castro Morales and Alberto Darias Príncipe, Al-Andalus: una identidad compartida: arte, ideología y enseñanza en el protectorado español en Marruecos (Madrid: Universidad Carlos III de Madrid, 1999), 167-171.
} 
Franco's seizure of power in Morocco in 1936 ushered in a shift in policy and official rhetoric that further favored vocational education. In 1937, Nationalist authorities launched plans to create Muslim vocational schools [escuelas profesionales musulmanas]. Like the vocational schools of the French sector, they were designed to give students with a preexisting basic education a combination of general knowledge, theoretical knowledge, and practice in given trades. As clarified in the regulations of 1942, these schools, now known as Moroccan schools of vocational orientation [escuelas marroquies de orientación profesional], offered instruction in four trades: carpentry, leather embossing, printing and bookbinding, and mechanics and electricity. ${ }^{72}$ Under Franco, Moroccan education emphasized racial and class separation in the pursuit of utilitarian ends. A reordering of the colonial education ministry and name changes in schools in the late 1930s reflected strict separation between Spanish and Moroccan education. The new high commissioner, Juan Beigbeder, stressed to teachers that the mission of the schools was vocational and/or practical, not intellectual or universalist, derogatory values associated with the Republic. Like Hardy before them, educators proudly proclaimed the motto of "school for life" [ la escuela para la vida]. Yet under Franco, the rhetoric became even less equivocal about the segregational aims of their policy, explicitly attempting to freeze Moroccans in their religious, class, and rural settings, echoing important themes for Franco on the mainland. ${ }^{73}$

The Vichy regime in France implemented similar intensifications in vocational education policy. Senior Vichy officials strongly promoted manual labor as a moral good and vocational education as a means of regulating and civically molding youth. Despite insufficient budgets, the number of vocational schools and guidance centers increased, and the latter directed students more unswervingly toward the manual trades. Commercial and industrial schools [écoles pratiques de commerce et d'industrie] were renamed colleges techniques, conferring on them greater prestige by suggesting their equivalence with the schools that fed into academic lycées. Furthermore, officials mandated minimum salaries for apprentices. Meanwhile, even schools not specially designated as vocational schools consolidated the place of manual work in the curriculum.

\footnotetext{
${ }^{72}$ Valderrama, Estado actual and Ibid., Historia de la acción cultural de España en Marruecos, 1912-1956, 2 vols. (Tetuán, Morocco: Editora Marroquí, 1956).

${ }^{73}$ Ibid., 9, 15, 43, 63, 64.
} 
For example in 1942, the curriculum for Muslim rural schools dedicated 5 out of 30 hours a week for the youngest pupils to agriculture-a figure growing to 11.5 hours per week (out of 35 ) in the final two years, with most of the remaining time dedicated to Arabic, French, math, and writing. ${ }^{74}$ All of these measures were calculated to increase the prestige of manual labor and to expand its purview. Under the mantra of "work, family, country" [travail, famille, patrie], Vichy policymakers sought to reinforce social stability and freeze individuals in the positions into which they were born.

When the Fourth Republic built on Vichy foundations after 1945 and expanded vocational education, the impetus was not the preservation of social position and the dissolution of class conflict through hierarchical and corporatist harmony, as Vichy officials had hoped, but at least in theory, increased social mobility. In France, the postwar education reforms beneficial to vocational education, such as the creation of the baccalauréat technique and l'école unique, were embraced just as much for their egalitarian spirit and the prospect of social mobility through the prestige of education. Morocco in the late 1940s through independence in 1956 followed a similar trajectory, with the introduction of a baccalauréat technique and greater access to formalized degrees or certificates for trades and professions. However, the increasing prestige of vocational education and the manual trades was insufficient to counter demands for easier access to the more theoretically oriented lycées, to higher positions within the government, and for greater power for organized labor.

Moreover, vocational training continued to primarily attract and benefit European and indigenous Jewish students. European students and Moroccan Jews disproportionately attended-and completed-technical and vocational education. Even in absolute terms, Muslim students comprised a minority of those who completed technical, vocational, and professional certificates, even in the postwar period when Muslim school enrollment steadily increased. It is perhaps unsurprising that the most prestigious technical, vocational, and professional qualifications, specifically, the baccalauréat technique, went exclusively to non-indigenous students in 1950 (with the exception of one Moroccan Jew), as did a disproportionate number of recipients of a brevet or CAP (certificat d'aptitude professionnel). In contrast, the only certificate with a majority of

${ }^{74}$ Katan, L'école, 119. 
Muslim recipients was the more humble, certificat d'apprentissage. What is more surprising is that European and Jewish students comprised fourfifths of all recipients of technical, vocational, and professional qualifications. For example, in 1950, 451 French and foreign (almost entirely all European) students received professional, vocational, and technical degrees and certificates ( $74 \%$ of the total). In comparison, there were 122 Muslim students (20\% of the total) and 38 Jewish students $(6 \%$ of the total). This was despite the fact that Moroccan Jews comprised 1.6\% of the total population and French and foreigners 3.8\% of the population, and despite the fact that Muslim students finally comprised a small majority of the secondary school population in the postwar period, up significantly from the 1920s. ${ }^{75}$ Roughly speaking (as the proportional representation of each group in the total population does not correspond precisely to their proportional representation in the school-age population, and bearing in mind that successful completion does not correspond to enrollment), Moroccan Jewish students were approximately four times more likely to complete vocational education than the size of the population would suggest, French and foreign students were almost twenty times more likely to complete vocational education, and Muslim students were nearly five times less likely to complete vocational education than the size of the population would suggest.

\section{CONCLUSION}

French vocational education policy in Morocco undeniably failed to meet the needs and aspirations of many of its inhabitants during the interwar period. In many places and for many groups, the interwar expansion of education, scholarization of vocational training, and adaptation to the supposed needs of different pupils was repeatedly marked with disappointments: underwhelming interest among prospective pupils and their families, limited employer engagement and job placement, and constant suspicion that vocational tracks would reinforce disadvantage, rather than provide social mobility. Certainly, the "ethnological discourse and doctrine" of Georges Hardy and Louis Brunot, which dominated the "political and intellectual culture of the colonial educational system [and] blinded the colonizers to the economic and cultural agendas of

${ }^{75}$ Calculated from Katan, L'école, 111, 114. 
Moroccan Muslims..." contributed greatly to this, as previously scholars have acknowledged. ${ }^{76}$

Yet, viewing interwar Moroccan education as not just colonial education - in the customary sense of education for the colonizedhas the potential to reveal both its international contours-situated as it was in a global movement to increase vocational training and vocational orientation-and its non-Muslim beneficiaries. As the vocational surveys, certificate recipients, and qualitative reports suggest, European and indigenous Jewish students school leavers were more likely to consciously embrace manual and industrial careers than Muslim school leavers. Students in European schools were encouraged to and did in fact embrace fields like mechanics or engineering that required strong specialization and familiarity with modern machines and techniques. These students were more likely than students in Muslim schools to receive an education in manual trades during or after public schooling, perhaps through an apprenticeship with a European-controlled firm arranged through a local office for vocational guidance. While Muslims were also encouraged to adopt "European jobs" in vocational schools, the trades they learned were often in less capital-intensive fields like woodworking, even if students were instructed in modern techniques. Moreover, Muslim students and families in the public education system generally preferred bureaucratic jobs.

In contrast, indigenous Jewish students were highly shaped by vocational education policies. The Alliance Israélite Universelle had a long history of promoting manual trades. This strategy grew out of a French discourse that sought to "redeem" Jews from the perceived dangers of work in the service sector, either because they regarded such tertiary sector work as non-productive or to counterstereotypes. Moreover in Morocco, Jews were at a disadvantage in hiring for the sultan's government, both before and after the establishment of the protectorate. They also faced discrimination in the traditional, Muslim-dominated apprenticeship system. ${ }^{77}$ Thus, a disproportionate number of Jewish students, facing discrimination and with limited job prospects with a normal school degree, enrolled in vocational schools as a means of attaining social mobility unavailable through other routes.

\footnotetext{
${ }^{76}$ Segalla, Moroccan Soul, 154.

${ }^{77}$ Saisset, "Le rôle de l'école dans les échanges franco-marocains," Bulletin de l'enseignement public du Maroc, no. 78 (January 1927): 21.
} 
Looking at the broader population of students in the Moroccan educational system, this social mobility was limited and not always the most common outcome. However, substantial upward social mobility was not typically the goal of providers of vocationally inflected education. Vocational training-and broader efforts, such as vocational orientation to match students with careers-generally maintained racial, religious, gender, and class hierarchies. This was consistent with the goal to preserve social stability, rather than simply a failure to achieve goals, even if some of the vocational schools and curricula failed to fulfill the aspirations of their students and teachers. It was not that vocational education-or colonial education, more broadly-was designed to fail the indigenous population; rather, it was only partially designed with the indigenous population in mind. Thus, the growing Moroccan economy, which became more closely integrated in the metropolitan and global economy, could for many years rely on colonial education, including vocational education, to provide skilled workers, even as the same educational system left many indigenous Moroccan children unschooled, segregated, and underskilled to participate in the emerging economy. Yet the rejection of many Muslim families (certainly more privileged Muslim families) of vocational education, and more crucially, the shortcomings of vocational education for Muslim students, reinforced European domination of - and to a limited and unequal extent, Moroccan Jewish participation in-the so-called modern economic sector, and its industry, commerce, and exports.

\section{BIBLIOGRAPHY}

Baldoui, Hainaut, and Le Gozler. "Les écoles professionnelles et l'art indigène." Bulletin de l'enseignement public du Maroc, no. 72 (February 1926): 60-63.

Barthélémy, Pascale, Emmanuelle Picard, and Rebecca Rogers, eds. "L'enseignement dans l'empire colonial français (XIXe-XXe siècles)." Histoire de l'éducation 128 (2010).

Belhaj Saif, Mohammed Rachid. "La politique scolaire du protectorat français au Maroc, 1912-1940.” Thèse État, Université René Descartes Paris V, 1994.

Bello, Luis. Viaje por las escuelas de España, vol. 4. Madrid: Magisterio español, 1926.

Benchekroun, Mohamed b. A. L'éducation et l'enseignement au Maroc à travers les documents français et espagnols,1912-1956: essai de bibliographie critique. Rabat: [s.n.], 1985.

Betts, Raymond F. Assimilation and Association in French Colonial Theory, 18901914. New York: Columbia University Press, 1961. 
Bidwell, Robin. Morocco Under Colonial Rule. New York: Routledge, 1973.

Brunot, Louis. "Certificat d'études primaires et apprentissage." In Premiers conseils, 203-204. Rabat: Ecole du Livre, 1934.

—. "Circulaire aux directeurs des écoles rurales et des écoles urbaines donnant un enseignement agricole." In Premiers conseils, 183-186. Rabat: Ecole du Livre, 1934.

_. "Comment pensent nos élèves marocains." In Premiers conseils, 175-182. Rabat: Ecole du Livre, 1934.

- "Histoire de l'enseignement des indigènes musulmans." In Premiers conseils, 131-151. Rabat: Ecole du Livre, 1934.

_. "L'action colonial et les mentalités indigènes." In Premiers conseils, 153-164. Rabat: Ecole du livre, 1934.

Bude, Udo. "The Adaptation Concept in British Colonial Education." Comparative Education 19, no. 3 (1983): 341-355.

Camiscioli, Elisa. Reproducing the French Race. Durham, NC: Duke, 2009.

Castro Morales, Federico, and Alberto Darias Príncipe. Al-Andalus: una identidad compartida: arte, ideología y enseñanza en el protectorado español en Marruecos. Madrid: Universidad Carlos III de Madrid, 1999.

Charlot, Bernard, and Madeleine Figeat. Histoire de la formation des ouvriers, 1789-1984. Collection Voies de l'histoire. Paris: Minerve, 1985.

Colonna, Fanny. Instituteurs algériens, 1883-1939. Travaux et recherches de science politique, no 36. Paris: Presses de la Fondation nationale des sciences politiques, 1975.

Congrès de l'Enseignement Professionnel Indigène [Rabat 1925]. "Situation des écoles d'apprentissage d'indigènes actuellement existantes." Bulletin de l'enseignement public du Maroc, no. 72 (February 1926): 76-93.

Conklin, Alice. A Mission to Civilize: The Republican Idea of Empire in France and West Africa, 1895-1930. Stanford: Stanford University Press, 1997.

Cooper, Frederick. Decolonization and African Society: The Labor Question in French and British Africa. Cambridge: Cambridge University Press, 2010.

Crubellier, Maurice. L'école Républicaine 1870-1940: Esquisse d'une histoire culturelle. Paris: Editions Christian, 1993.

Danvers, Francis, and Michel Huteau. Le conseil en orientation en France de 1914 à nos jours. Issy-les-Moulineaux, France: Editions EAP, 1988.

Fradera, Josep M. "La Plus Grande France: el ciudadano y su negación en la República imperial." In La nación imperial, vol. 2, 973-1053. Barcelona: Edhasa, 2015.

Gaudefroy-Demombynes, Roger. L'xuvre française en matière d'enseignement au Maroc. Paris: Librairie orientaliste P. Geuthner, 1928.

Gauthier, Edouard. "L'orientation professionnelle." Revue Internationale du Travail 5, no. 5 (May 1922): 759-773. 
Gotteland, Jean, and Mlle Alphandery. "A propos d'Orientation professionnelle." Bulletin de l'enseignement public du Maroc (November-December 1932): 449-454.

Hardy, Georges. “Du souq à l'usine: Congrès de l'Enseignement Professionnel Indigène." Bulletin de l'enseignement public du Maroc, no. 72 (February 1926): 1-18.

—. L'âme marocaine d'après la littérature française. Paris: É. Larose, 1926.

_. "Les vocations de nos élèves." Bulletin de l'enseignement public du Maroc [series] (April 1924): 211-266; (May 1925): 255-313; (May-June-July 1926): 82-144.

Hardy, Georges, and Louis Brunot. L'enfant marocain: Essai d'etnographie scolaire. Paris: E. Larose, 1925.

Jacquemet. "L'école primaire et l'orientation professionnelle." Bulletin de l'enseignement public du Maroc, no. 58 (April 1924): 267-272.

Katan, Yvette. “L'école, instrument de la modernisation sous le protectorat français au Maroc?” Mediterrán tanulmányok 5 (1993): 99-119.

Knibiehler, Yvonne. “L’enseignement au Maroc pendant le protectorat (1912-1956): Les 'fils de notables'." Revue d'histoire moderne et contemporaine 41, no. 3 (July-September 1994): 489-498.

Kuster, Sybille. “'Book Learning' versus 'Adapted Education': The Impact of Phelps-Stokesism on Colonial Education Systems in Central Africa in the Interwar Period." Paedagogica Historica 43, no. 1 (2007): 79-97.

Lisard, M. "L'orientation professionnelle au Maroc: Organisation et fonctionnement du Bureau d'Orientation professionnelle de Casablanca (Année 1927-1928)." Bulletin de l'enseignement public du Maroc, no. 93 (January 1929): 13-27.

Lorcin, Patricia M. E. Imperial Identities: Stereotyping, Prejudice and Race in Colonial Algeria. Society and Culture in the Modern Middle East. London: I.B. Tauris, 1995.

Loth, Gaston. "Règlement scolaire," Bulletin de l'enseignement public du Maroc, no. 1 (June 1914): 1 .

Maier, Charles S. In Search of Stability: Explorations in Historical Political Economy. Cambridge: Cambridge University Press, 1987.

Manière, Laurent. "La politique française pour l'adaptation de l'enseignement en Afrique après les indépendances (1958-1964)." Histoire de l'éducation, no. 128 (2010): 163-190.

Marty, Paul. Le Maroc de demain. Paris: Comité de l'Afrique française, 1925.

Mauguière et Achille. "Le problème de la culture générale." Bulletin de l'enseignement public du aroc, no. 72 (February 1926): 31-34.

Morisson and Montel. "Le recrutement des élèves et la fréquentation." Bulletin de l'enseignement public du Maroc, no. 72 (February 1926): 19-30.

Morocco. Direction Générale de l'instruction publique, des beaux-arts et des antiquités (DIP). Historique, 1912-1930. Rabat: Imprimerie de l'École du livre, 1930. 
Paye, Lucien. Introduction et évolution de l'enseignement moderne au Maroc. Paris: [s.n.], 1957.

Pelpel, Patrice, and Vincent Troger. Histoire de l'enseignement technique. Pédagogies pour demain. Paris: Hachette Education, 1993.

Rist, Gilbert. The History of Development: From Western Origins to Global Faith. Translated by Patrick Camiller. London: Zed Books, 2010.

Roberts, Mary Louise. Civilization Without Sexes: Reconstructing Gender in Postwar France, 1917-1927. Series Women in Culture and Society. Chicago: University of Chicago Press, 1994.

Rockwell, Elsie. "Tracing Assimilation and Adaptation through School Exercise Books from Afrique Occidentale Française in the Early Twentieth Century." In Empire and Education in Africa, edited by Peter Kallaway and Rebecca Swartz, 235-270. New York: Peter Lang, 2016.

Rodríguez, José María. "Labor pedagógico-cultural de los franciscanos en Marruecos." In Segunda serie de trabajos leídos en la Semana de misiología de Barcelona (29 de junio a 6 de julio de 1930). Barcelona: Escuela Tipográfica Salesiana, 1930.

Saisset. "Le rôle de l'école dans les échanges franco-marocains." Bulletin de l'enseignement public du Maroc, no. 78 (January 1927): 12-27.

Segalla, Spencer D. The Moroccan Soul: French Education, Colonial Ethnology, and Muslim Resistance, 1912-1956. Lincoln: University of Nebraska, 2009.

Thomas, Martin. "Albert Sarraut, French Colonial Development, and the Communist Threat, 1919-1930." Journal of Modern History 77, no. 343 (December 2005): 917-955.

Tselikas, Effy, and Lina Hayoun. Les lycées français du soleil: Creusets cosmopolites du Maroc, de l'Algérie et de la Tunisie. Mémoires, no. 99. Paris: Autrement, 2004.

Unger, Corinna R. International Development: A Postwar History. London: Bloomsbury, 2018.

Valderrama Martinez, Fernando. Estado actual de la enseñanza marroqui. Ceuta: Imperio, 1939.

- Historia de la acción cultural de España en Marruecos, 1912-1956, 2 vols. Tetuán, Morocco: Editora Marroquí, 1956.

Vedel, J. "Les élèves espagnols des écoles du Maroc." Bulletin de l'enseignement public du Maroc, no. 56 (February 1924): 141-147.

Velu, H. "L'enseignement agricole élémentaire." Bulletin de l'enseignement public du Maroc, no. 89 (May 1928): 156-161.

Wright, Gwendolyn. The Politics of Design in French Colonial Urbanism. Chicago: University of Chicago Press, 1991. 
Open Access This chapter is licensed under the terms of the Creative Commons Attribution 4.0 International License (http://creativecommons.org/licenses/ by $/ 4.0 /$ ), which permits use, sharing, adaptation, distribution and reproduction in any medium or format, as long as you give appropriate credit to the original author(s) and the source, provide a link to the Creative Commons license and indicate if changes were made.

The images or other third party material in this chapter are included in the chapter's Creative Commons license, unless indicated otherwise in a credit line to the material. If material is not included in the chapter's Creative Commons license and your intended use is not permitted by statutory regulation or exceeds the permitted use, you will need to obtain permission directly from the copyright holder.

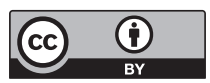

